\title{
Pembangunan Aplikasi Task Management dalam Mendukung Proyek Pengembangan Perangkat Lunak (Studi Kasus : PT.eBdesk Indonesia)
}

\author{
Rauf Fauzan ${ }^{1}$, Irpan Bangga Nugraha ${ }^{2}$ \\ Program Studi Sistem Informasi Universitas Komputer Indonesia \\ Jl. Dipatiukur No.112-114 Kota Bandung \\ rauffauzan@email.unikom.ac.id \\ Program Studi Sistem Informasi Universitas Komputer Indonesia \\ Jl. Dipatiukur No.112-114 Kota Bandung \\ irpanabdg.ebdesk.com
}

\begin{abstract}
Scheduling on tasks and the employee arrangements in the field is extremely important, due to the increasing tasks continuously. Today, scheduling an employee in the field is considered very weak, this can be inferred from the number of the employees who unable to take the advantage of the given time by the company to finish the job. The information system of Task Management Web-Based Using PHP and MySQL as a tool to support the process of scheduling and field arrangements as well as facilitate the leader and its members in the process of creating new applications in PT eBdesk Technology. In addition, this application can help leaders and subordinates in making daily schedules to clarify activities that must be done every day. This system can help the leader to manage the risks that may occur during project work. In this research, the author wants to build an application web-based management using programming language of $\mathrm{PHP}$ and MySQL database. So leaders and members can access the application in real time. Which is expected to provide the facilitate of organization in performing the scheduling.
\end{abstract}

Intisari- Penjadwalan terhadap tugas-tugas dan pengaturan pegawai ditempat kerja sangatlah penting, hal ini dikarenakan jumlah tugas-tugas dan pegawai di lapangan semakin terus bertambah. Penjadwalan pegawai di lapangan saat ini dirasa masih sangat lemah, hal ini dapat dilihat dari masih banyaknya pegawai yang tidak mampu memanfaatkan waktu yang diberikan suatu perusahaan untuk menyelesaikan tugasnya. Sistem Informasi Task Management Berbasis Web Menggunakan PHP dan MySQL dimaksudkan sebagai alat yang mendukung proses penjadwalan dan pengaturan ditempat kerja serta mempermudah leader dan anggotanya dalam proses pembuatan aplikasi baru di PT eBdesk Teknologi. Selain itu, aplikasi ini dapat membantu para leader juga bawahannya dalam pembuatan jadwal harian untuk memperjelas kegiatan yang harus dikerjakan setiap harinya. Sistem ini dapat membantu leader untuk mengelola resiko yang mungkin terjadi pada saat pengerjaan proyek. Dalam penelitian ini, penulis ingin membangun suatu aplikasi task managament berbasis web menggunakan bahasa pemrograman PHP dan database MySQL sehingga leader maupun anggota dapat mengkses aplikasi secara realtime. Serta yang diharapkan dapat memberikan kemudahan kepada suatu organisasi dalam melakukan penjadwalan tersebut.
Kata Kunci: Aplikasi, Task Management, PHP MySQL.

\section{Pendahuluan}

Pertambahan pelaku bisnis di bidang pembangunan perangkat lunak semakin meningkat, sehingga persaingan bisnis dalam bidang pembangunan perangkat lunak semakin meningkat juga. PT eBdesk Teknologi sebagai pelaku bisnis yang sudah lama berkecimpung dalam bidang pembangunan perangkat lunak perlu pemikiran cara agar usaha dalam bisnis tersebut dapat memperoleh keuntungan meningkat.

PT eBdesk Teknologi merupakan sebuah perusahaan yang bergerak di bidang pembangunan perangkat lunak. Perusahaan ini didirikan sejak tahun 1998 yang berpusat di Jakarta dan memiliki beberapa cabang, salah satunya yang berada di Bandung. Berdasarkan hasil wawancara dengan Leader divisi Monitoring bahwa di setiap tahunnya perusahaan ini biasa menangani 5-7 proyek, proyek yang ditangani bervariasi seperti eBdesk eXpander Corporate portal, eXpedition Workflow, eNcyclo Document Management, dan eXpert Knowledge Management. PT eBdesk Teknologi terkadang menangani 2 sampai 3 aplikasi yang harus dikerjakan dalam waktu bersamaan. Hal tersebut menjadi keuntungan bagi perusahaan, akan tetapi di sisi lain hal itu menimbulkan masalah bagi perusahaan. Masalah yang terjadi adalah kesulitan dalam proses pengawasan pegawai dalam pembuatan aplikasi, karena pegawai harus mengerjakan double-task sehubungan dengan minim nya pegawai yang idle. Hal tersebut menyebabkan keterlambatan dalam penyelesaian proyek, karena proyek yang tidak terawasi dengan baik.

Selain itu masalah lain terjadi karena jadwal yang dibuat hanya menggunakan perkiraan kasar yang dilakukan oleh leader atau pegawai, terkadang mengakibatkan melesetnya waktu penyelesain pekerjaan dengan waktu yang telah diperkirakan sebelumnya. Manager QA (Quality Assurance) PT eBdesk Teknologi juga menyampaikan hambatanhambatan yang terjadi saat pengerjaan aplikasi baru seperti 
pekerja yang berhalangan hadir dikarenakan sakit, keterlambatan memberikan task (job assignment) dari leader, dan double-task yang diterima pegawai sehingga pengerjaan menjadi lambat. Resiko tersebut sering kali muncul saat dalam proses pengerjaan proyek, tentu hal tersebut menghambat proses pengerjaan proyek.

Berdasarkan dari permasalahan yang telah diuraikan sebelumnya maka dapat disimpulkan bahwa inti masalah yang terjadi adalah keterlambatan dan pengerjaan ganda oleh pegawai dalam waktu bersamaan pada saat pelaksanaan proyek. Hal tersebut mengakibatkan berkurangnya keuntungan perusahaan dikarenakan harus mengeluarkan biaya lebih untuk membayar tambahan jam kerja pegawai atau operasional. Oleh karna itu diperlukan suatu sistem yang dapat membantu leader dan anggotanya dalam proses pembuatan aplikasi baru di PT eBdesk Teknologi. Sesuai dengan tujuan penelitian ini, penulis ingin membangun aplikasi baru yang dinamakan Task Management di PT. eBdesk Teknologi, untuk memudahkan leader dan anggotanya dalam mengelola pekerjaan-pekerjaan pada suatu proyek serta mengimplementasikan dalam bentuk apllikasi berbasis web. Dengan itu, aplikasi dapat diakses di manapun pegawai berada. Selain itu, aplikasi memudahkan leader dalam proses monitoring proyek yang terkadang posisi leader sering tidak ada di tempat atau kantor.

Manfaat bagi pihak terkait dengan penelitian ini adalah dapat mengembangkan Sistem Informasi Taks Management pada perusahaan PT. eBdesk Teknologi yang sedang berjalan menjadi sistem yang terorganisir, sehingga dapat memberikan informasi secara cepat, tepat, dan akurat serta relevan dan tepat waktu agar dapat membantu proses mengerjakan proyek.

\section{LANDASAN TEORI}

\section{A. Tinjauan Pustaka}

Penelitian tentang pengaruh pengawasan supervisor terhadap kinerja karyawan dengan studi kasus AMIGO GROUP Cabang Granada Delanggu berfokus pada memperbaiki kinerja karyawan yang ada di AMIGO GROUP [1]. Persamaan konten penelitiannya yaitu membuat pengawasan dalam proyek atau mendistribusikan pekerjaanpekerjaan kepada karyawan supaya lebih tepat sasaran dan juga dapat mengontrol progress harian dan pengaruh kinerja karyawan terhadap prestasi kerja karyawan. Sedangkan perbedaanya yaitu penelitian tersebut hanya sebatas model, dan tidak diimplementasikan ke dalam aplikasi.

Penelitian lain, yaitu tentang pengembangan aplikasi promanage (proyek manajemen) berbasis web dengan studi kasus CV. Ixosoft Online Solutio, bertujuan untuk dapat membuat aplikasi yang mempermudah manager dalam memonitor proyek dan mempermudah stakeholder dalam pertukaran data dan informasi. Penulis menggunakan metodologi penelitian ptototype yaitu dengan cara mendengarkan pelanggan, membangun/memperbaiki prototype, dan menguji prototype, kemudian ditemukanlah pemecahan masalah oleh peneliti yaitu dengan Perancangan Aplikasi Promanage (Proyek Manajemen) Berbasis Web [2].

Persamaan konten penelitiannya yaitu membuat aplikasi task management dan mendistribusikan task berbasis web dengan menggunakan metode penelitian prototype, dengan desain penelitian deskriptif, dan alat bantu untuk menggambarkan sistem menggunakan UML (Unified Modeling Language). Perbedaannya yaitu penelitian tersebut tidak terdapat proses bug-fixing.

\section{B. Task Management}

Task Management adalah aktivitas di mana seorang individu atau pemimpin tim melacak sebuah tugas sepanjang siklus hidup sistem dan membuat keputusan berdasarkan kemajuan sistem. Task Management dilakukan dengan menggunakan perangkat lunak yang membantu mengatur dan mengelola tugas dengan efektif dengan menggunakan fungsi seperti pembuatan tugas, perencanaan dan penugasan, pelacakan dan pelaporan [3].

Laporan yang dihasilkan oleh aplikasi Task management membantu manajemen dalam menganalisis efisiensi keseluruhan individu dan pekerjaan yang telah didistribusikan. Aplikasi Task Management digunakan untuk melacak task pribadi atau task bersama. Aplikasi bisa berupa perangkat lunak dan dijalankan LAN-based atau Web-based. Ukuran dan fungsi aplikasi bergantung pada persyaratan tugas dan apakah aplikasi tersebut digunakan untuk bisnis individu, usaha kecil atau menengah atau untuk aktivitas pengelolaan tugas perusahaan [3]. Fitur Task Management meliputi:

1. Pembuatan Tugas.

2. Assignment PIC (Personal In Charge).

3. Mendristribusikan Tugas.

4. Ringkasan Pembagian Tugas.

5. Proses Bug-Fixing.

6. Laporan Pengerjaan Tugas

\section{Perangkat lunak dan Program Aplikasi}

Perangkat lunak merupakan bagian terpenting dalam dunia teknologi informasi. Kaitannya, perangkat lunak merupakan bagian dari teknologi informasi. Perangkat lunak terdiri dari bagian-bagian seperti; source code, aplikasi dan logika-logika penting. [4]

Program merupakan ekspresi, pernyataan kombinasi yang disusun dan dirangkai menjadi satu kesatuan prosedur yang berupa urutan langkah untuk menyelesaikan masalah yang diimplementasikan dengan menggunakan bahasa pemrograman, sehingga dapat dieksekusi oleh komputer. Sedangkan aplikasi adalah suatu penerapan, menyimpan sesuatu hal, data, permasalahan pekerjaan ke dalam suatu sarana atau media yang digunakan untuk menerapkan atau mengimplementasikan hal atau permasalahan tersebut sehingga berubah menjadi suatu bentuk yang baru tanpa menghilangkan nilai-nilai dasar dari hal, data, permasalahan atau pekerjaan [5].

Program Aplikasi adalah sederetan kode yang digunakan untuk mengatur komputer agar dapat melakukan pekerjaan sesuai dengan keinginan dari permasalahan pengguna [5].

\section{METODOLOGI PENELITIAN}

\section{A. Metode Penelitian}

Metode Penelitian yang digunakan adalah metode Action Research (penelitian tindakan). Metode Action Research adalah suatu bentuk penelitian reflektif diri secara 
kolektif dilakukan peneliti dalam situasi sosial untuk meningkatkan penalaran dan keadilan pratek pendidikan sosial mereka, serta pemahaman mereka mengenai praktek dan terhadap situasi tempat dilakukan praktek-praktek tersebut. [6]

\section{B. Metode Pengembagan Sistem}

Metode pengembangan sistem yang digunakan dalam membangun aplikasi Task Management adalah metode pengembangan sistem prototype.

Secara umum tahapan pada model prototyping terdiri dari 3 tahapan: mendengar, membangun dan menguji. Ketiga tahapan tersebut, secara jelas dapat dilihat pada Gambar. 1:

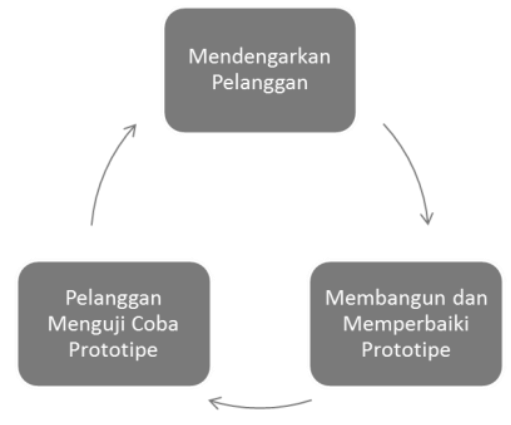

Gambar. 1. Metode Pengembangan Sistem

\section{Alat Bantu}

Pada rancangan sistem informasi Task Management ini, penulis menggunakan metode pendekatan berorientasi objek. Berikut beberapa alat bantu dalam merancang system iantaranya Diagram use-case (use case diagram); Skenario use case; Diagram aktivitas (activity diagram); Diagram sekuen (sequence diagram); Diagram kelas (Class diagram); Diagram komponen (Component diagram) dan Diagram deployment (Deployment diagram)

\section{HASIL DAN ANALISIS}

\section{A. Analisis Sistem}

Berikut beberapa hasil analisis sistem berjalan saat ini yang akan digambarkan menggunakan prosedur dan diagram use case srta evaluasi sistem, berikut hasilnya ;

1. Prosedur pembuatan aplikasi baru :

- CEO, CTO dan leader dari setiap divisi development melakukan meeting di kantor pusat.

- CTO menganalisis usulan aplikasi baru yang diberikan oleh CEO.

- CTO memberikan hasil analisis berupa rancangan antarmuka atau pemakaian code kepada leader BE dan leader FE.

- Leader BE dan leader FE memberikan tugas-tugas kepada programmer BE dan FE.

- Programmer BE dan FE mengerjakan tugas yang telah diberikan oleh leader.

- Programmer BE dan FE mengecek aplikasi yang telah mereka kerjakan.
- Setelah selesai implementasi oleh programmer masuk ke dalam tahap pembuatan dokumen oleh QA.

- Setelah selesai membuat dokumen, QA melakukan testing secara keseluruhan.

- Apabila QA menemukan bug, segera dilaporkan kepada programmer untuk diperbaiki.

- CEO melihat aplikasi yang sudah jadi yang bebas dari bug.

- Tahap akhir dari Aplikasi baru dengan melakukan pemeliharaan aplikasi.

2. Use Case Diagram pembuatan aplikasi baru :

Use case diagram memperlihatkan pada kita hubunganhubungan yang terjadi antara aktor-aktor dengan use case dalam sistem. Adapun use case diagram yang saat ini berjalan pada PT. eBdesk Teknologi dapat dilihat pada Gambar. 2:

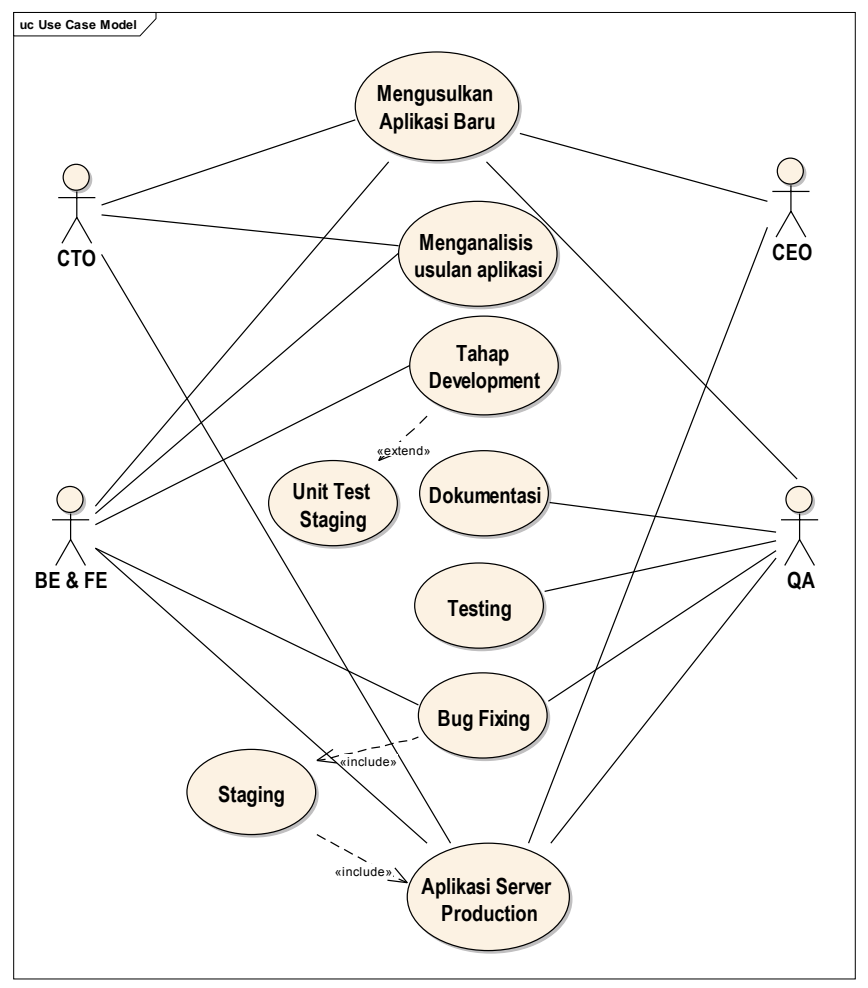

Gambar. 2. Use Case Diagram Pembuatan Aplikasi Baru

3. Evaluasi Sistem :

Evaluasi sistem yang berjalan adalah proses menemukan kesalahan, kekurangan, hambatan-hambatan yang terjadi pada sistem yang sedang berjalan. Sehingga dapat diusulkan pemecahan suatu masalah agar dapat menghasilkan, mengoptimalkan dan membantu proses pengeloaan sistem secara lebih baik, cepat dan akurat. Berikut beberapa evaluasi sistem dapat dilihat pada Tabel 1:

TABLE I

EVALUASI SISTEM YANG SEDANG BERJALAN

\begin{tabular}{|l|l|l|l|}
\hline No & Permasalahan & Pemecahan & Bagian \\
\hline
\end{tabular}




\begin{tabular}{|l|l|l|l|}
\hline 1. & $\begin{array}{l}\text { Mengeluarkan } \\
\text { banyak resource } \\
\text { seperti waktu, } \\
\text { kertas dan printer }\end{array}$ & $\begin{array}{l}\text { Pembuatan } \\
\text { Aplikasi task } \\
\text { management } \\
\text { secara } \text { online, } \\
\text { sehingga bisa } \\
\text { menghemat } \\
\text { resource }\end{array}$ & $\begin{array}{l}\text { All } \\
\text { Development } \\
\text { Team }\end{array}$ \\
\hline 2. & $\begin{array}{l}\text { Kesulitan dalam } \\
\text { mencari atau } \\
\text { menyusun } \\
\text { dokumen }\end{array}$ & $\begin{array}{l}\text { Pembuatan } \\
\text { fasilitas untuk } \\
\text { menyimpan dan } \\
\text { mencari data } \\
\text { secara online. }\end{array}$ & $\begin{array}{l}\text { QA } \\
\text { Development }\end{array}$ \\
\hline 3. & $\begin{array}{l}\text { Kesulitan dalam } \\
\text { mendistribusikan } \\
\text { task }\end{array}$ & $\begin{array}{l}\text { Pembuatan } \\
\text { fasilitas Backlog } \\
\text { (mendistribusikan } \\
\text { task) }\end{array}$ & $\begin{array}{l}\text { Programmer } \\
\text { Development }\end{array}$ \\
\hline 4. & $\begin{array}{l}\text { Kesulitan } \\
\text { melakukan } \\
\text { koordinasi antar } \\
\text { team untuk } \\
\text { implementasi } \\
\text { sistem }\end{array}$ & $\begin{array}{l}\text { Pembuatan } \\
\text { fasilitas status } \\
\text { progress feature }\end{array}$ & $\begin{array}{l}\text { All } \\
\text { Team }\end{array}$ \\
\hline
\end{tabular}

\section{B. Perancangan Sistem}

Sistem yang dibuat merupakan usulan perancangan sistem untuk memperbaiki sistem pengolahan project (yang selanjutnya akan disebut plan) dan task yang sedang berjalan sebelumnya. Maka solusi yang diusulkan adalah dengan membuat sistem informasi Task Management berbasis web, sistem informasi ini akan memuat fasilitas yang dibutuhkan sebagai berikut :

1. Kemudahan distribusi pekerjaan : Memungkinkan para leader memberikan task kepada timnya melalui sistem informasi Task Management.

2. Kemudahan pelaporan pekerjaan : Memungkinkan anggota tim melaporkan hasil pekerjaan nya melalui sistem informasi Task Management.

3. Kemudahan monitoring progress plan : Memungkinkan leader dan pihak manajemen lainnya untuk memantau progress plan.

4. Analisa dan Evaluasi : dengan visualisasi dalam bentuk grafik maka sistem dapat memberikan informasi yang berguna untuk kebutuhan analisa dan evaluasi. Analisa disini mencakup analisa progress suatu plan dan juga analisa sumber daya manusia, sehingga dari hasil analisa tersebut pihak menajemen dapat memberikan evaluasi kepada tim nya.

Berikut beberapa hasil dai perancangan sistem yang akan dibangun meliputi; perancangan basisdata, perancangan antarmuka dan perancangan arsitektur jaringan.

1. Perancangan Basisdata :

Berikut rancangan basisdata aplikasi Task Management yang akan dibangun dapat dilihat pada Gambar. 3 :

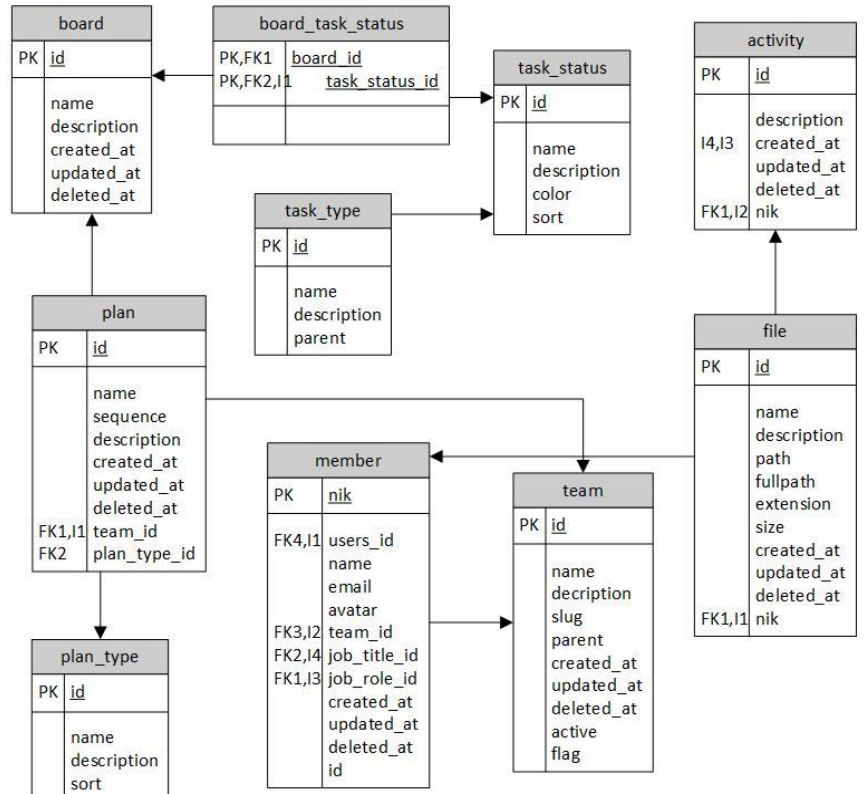

Gambar. 3. Perancangan Data Aplikasi Task Management

2. Perancangan Antarmuka Aplikasi :

Perancangan antarmuka meliputi, struktur menu, rancangan input dan rancangan output :Struktur menu pada system yang diusulkan dibagi 3 yaitu struktur menu untuk leader, member, dan admin. Struktur tersebut antara lain:

- Struktur Menu Halaman Leader

Berikut gambaran struktur menu aplikiasi Task Management untuk hak akses leader, dapat dilihat pada Gambar. 4:

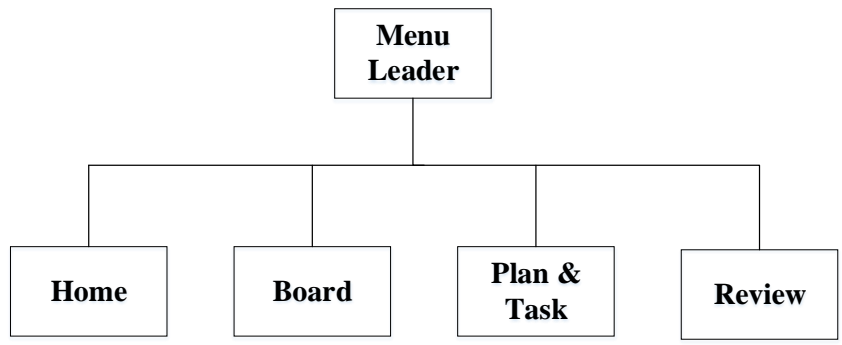

Gambar. 4. Struktur Menu Halaman Leader

\section{- Struktur Menu Halaman Member}

Berikut gambaran struktur menu aplikasi Task Management untuk hak akses Member, dapat dilihat pada Gambar 5:

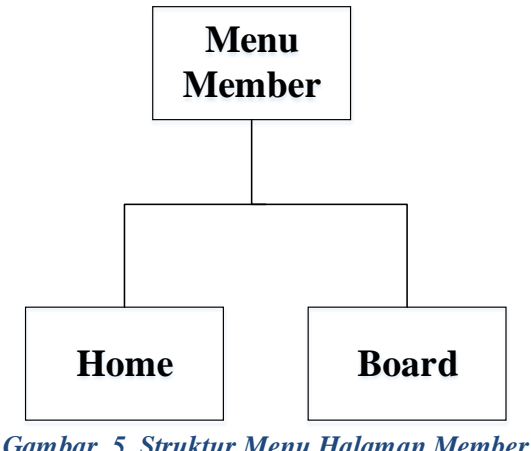

- Struktur Menu Halaman Admin 
Berikut gambaran struktur menu aplikiasi Task Management untuk hak akses Admin, dapat dilihat pada Gambar 6:

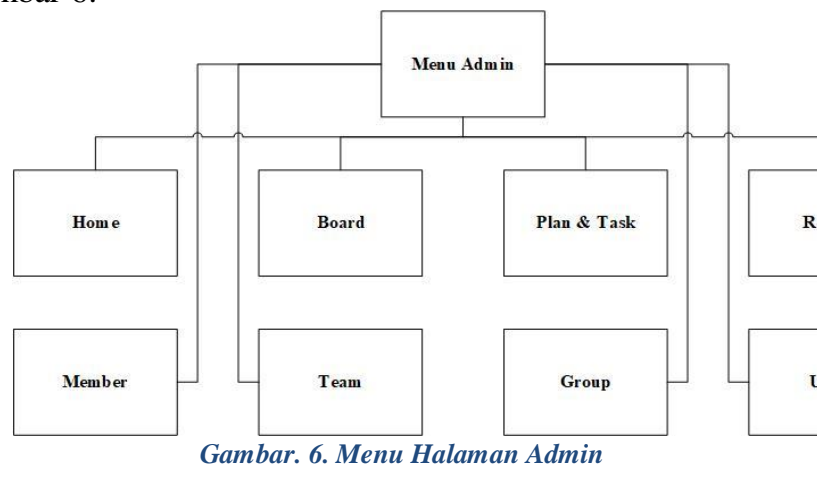

- Perancangan Tampilan Login

Tampilan Login ini berlaku untuk semua aktor, baik leader, member maupun admin. Berikut perancangan tampilan login dapat dilihat pada Gambar 7 :

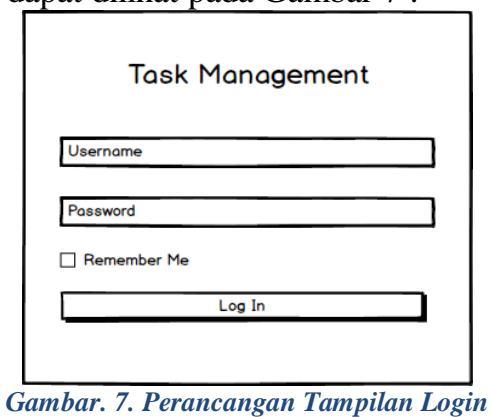

- Perancangan Tampilan Input Data Plan

Tampilan ini digunakan untuk memasukkan Plan/ rencana apa yang akan dilakukan, dan tugas akan diberikan kepada siapa. Berikut perancangan tampilan input data plan dapat dilihat pada Gambar. 8 :

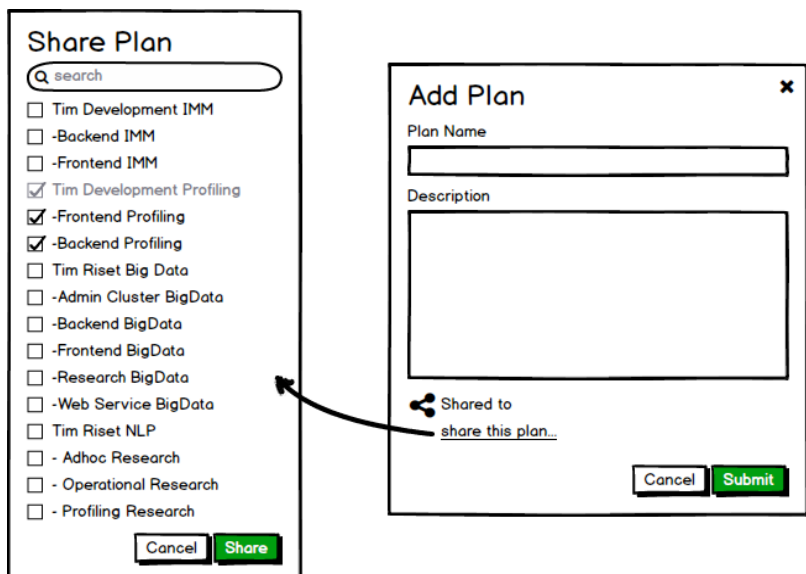

Gambar. 8. Perancangan Tampilan Input Data Plan

- Perancangan Tampilan Input Data Board

Berikut perancangan tampilan Input Data Board dapat dilihat pada Gambar. 9 :

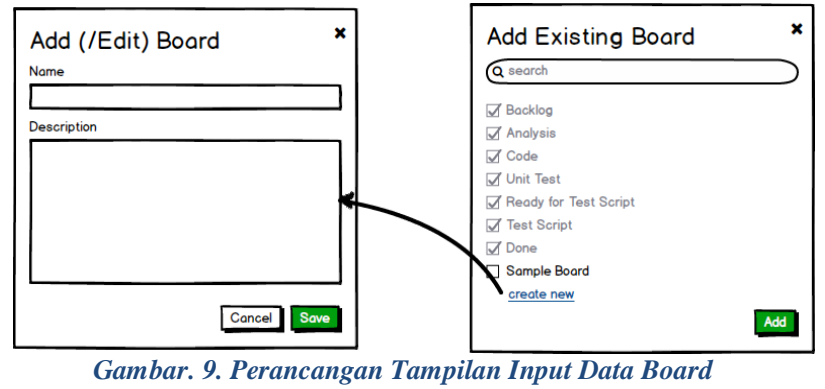

- $\quad$ Perancangan Tampilan Input Data Task

Berikut perancangan tampilan Input Data Task dapat dilihat pada Gambar 10 :

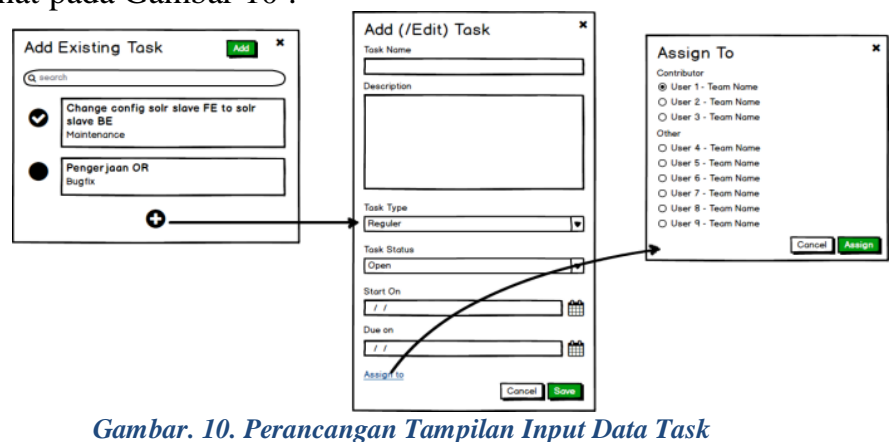

- Perancangan Tampilan Input Data Swimlane

Berikut perancangan tampilan Input Data Swimlane dapat dilihat pada Gambar 11 :

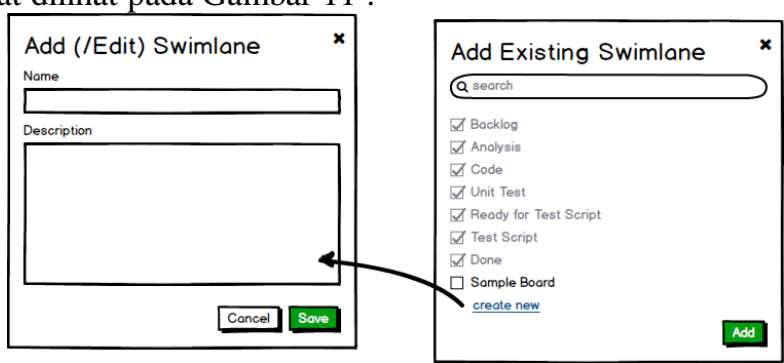

Gambar. 11. Perancangan Tampilan Input Data Swimlane

- Perancangan Tampilan Input Data Activity

Berikut perancangan tampilan Input Data Activity dapat dilihat pada Gambar 12 : 


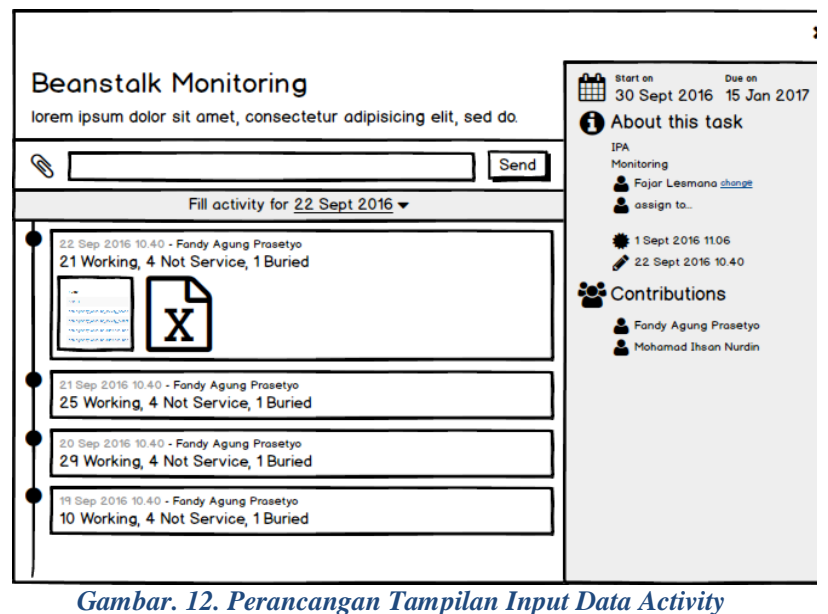

- Perancangan Tampilan Input Data Member

Berikut perancangan tampilan Input Data Member dapat dilihat pada Gambar 13 :

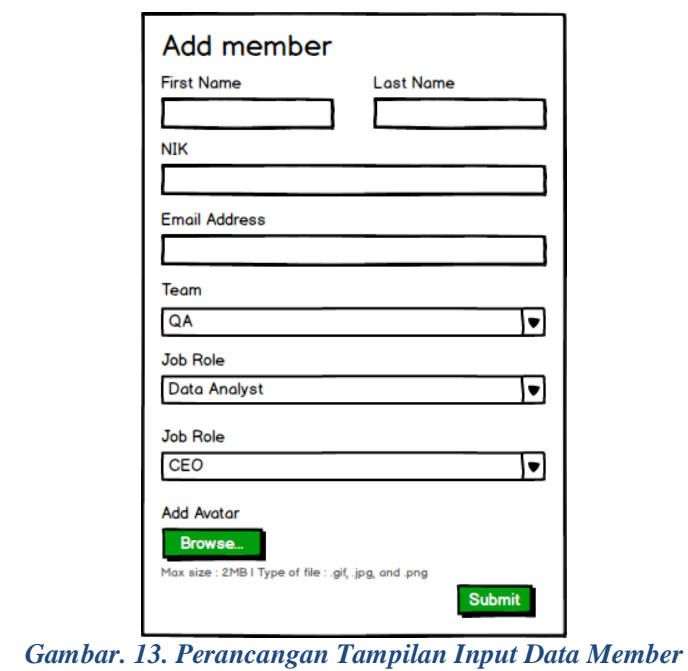

- Perancangan Tampilan Input Data Team

Berikut perancangan tampilan Input Data Swimlane dapat dilihat pada Gambar 14 :

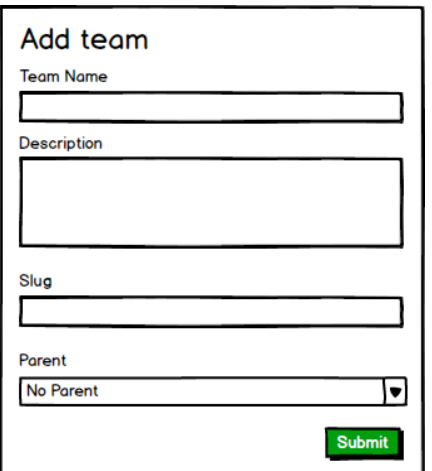

Gambar. 14 Perancangan Tampilan Input Data Team

- Perancangan Tampilan Output Monitoring Progress Plan

Tampilan output monitoring progress plan adalah tampilan untuk pengguna dapat memantau progress dari suatu plan yang sedang dikerjakan. Dalam tampilan ini pengguna dapat melihat task apa saja yang harus, sedang dan sudah dikerjakan. Berikut perancangan tampilan Output Monitoring Progress Plan dilihat pada Gambar. 15 :

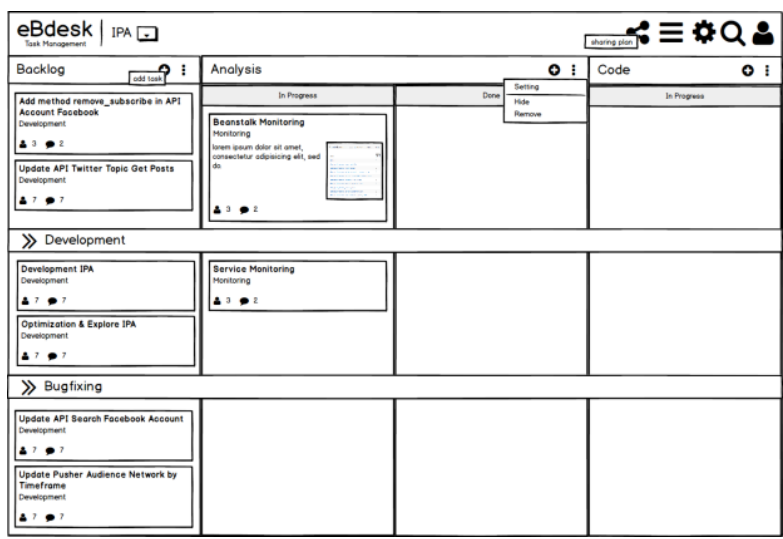

Gambar. 15. Perancangan Tampilan Output Monitoring Progress Plan

- Perancangan Tampilan Output Analisis dan Evaluasi

Tampilan Output Analisis \& Evaluasi ini berupa grafik User Repartition, Task Distribution dan Cumulative Flow Diagram yang mana digunakan untuk menganalisa apa aksi selanjutnya yang harus dilakukan untuk menyelesaikan suatu plan yang sedang dikerjakan secara efektif dan efisien. Berikut perancangan tampilan Output Analisa dan Evaluasi dapat dilihat pada Gambar. 16 :
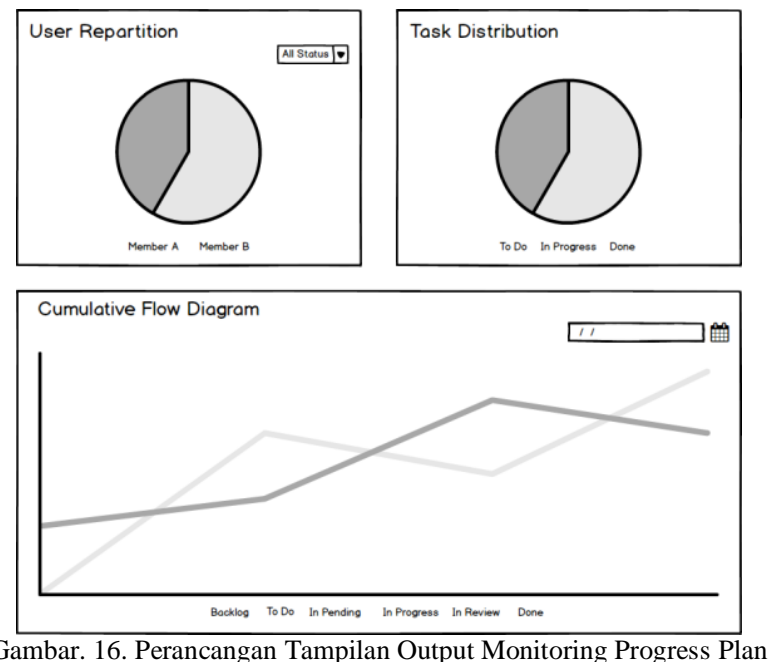

3. Perancangan Arsitektur Jaringan

Pada aplikasi Task Management, rancangan arsitektur jaringan yang digunakan adalah berbasis website, dan terdapat 1 server yang digunakan untuk menyimpan aplikasi dan database aplikasi Task Management. Berikut perancangan Arsitektur Jaringan aplikasi Task Management dilihat pada Gambar. 17 : 


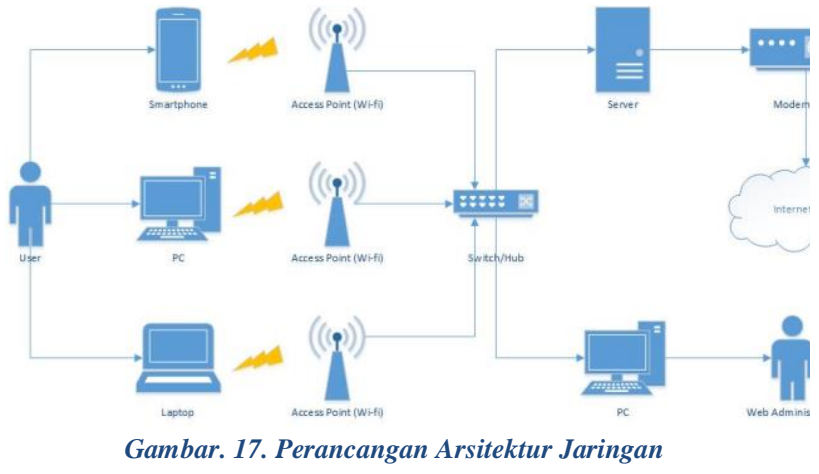

C. Implementasi Sistem

Proses implementasi dilakukan pada saat perangkat lunak telah selesai dikerjakan, tujuannya untuk mengetahui apa saja yang akan diterapkan.

1. Implementasi Software Pendukung :

Implementasi perangkat lunak dari aplikas ini memerlukan beberapa perangkat lunak pendukung seperti :

Kebutuhan Komputer Admin

- Sistem Operasi : Microsoft Windows 7/8/8.1/10

- Database menggunakan XAMPP 5.6.15-1

- Web Browser menggunakan Google Chrome dan Mozila Firefox

Kebutuhan Komputer User

- Sistem Operasi : Microsoft Windows 7/8/8.1/10

- Web Browser menggunakan Google Chrome dan Mozila Firefox

2. Implementasi Hardware :

Implementasi perangkat keras untuk mendukung aplikasi ini adalah :

Komputer Admin

- Processor : Intel Core i3 3.4 Ghz or Higher

- Memory : 4GB

- Hard Disk : 500GB

- VGA : Nvidia GT610 2GB or Higher

- Monitor : LED 14" resolusi 1366x768

- Mouse dan Keyboard

Komputer User

- Processor : Intel Core i3 3.4 Ghz or Higher

- Memory : 2GB

- Hard Disk : 320GB

- VGA : Nvidia GT610 1GB or Higher

- Monitor : LED 14" resolusi 1366x768

- Mouse dan Keyboard

3. Implementasi Basisdata :

Berikut struktur tabel pada tabel activity dapat dilihat pada Tabel 2:

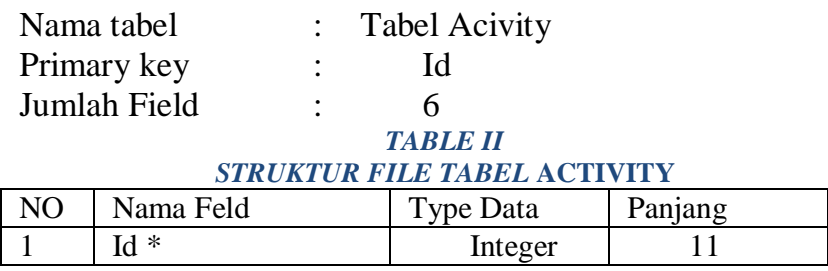

\begin{tabular}{|l|l|l|l|}
\hline 2 & Description & Text & \\
\hline 3 & Created_at & Datetime & \\
\hline 4 & Deleted_at & Datetime & \\
\hline 5 & Task_id $* *$ & Integer & 11 \\
\hline 6 & Nik $* *$ & Integer & 11 \\
\hline
\end{tabular}

Berikut struktur tabel pada tabel activity file dapat dilihat pada Tabel 3:

$\begin{array}{lcc}\text { Nama tabel } & : & \text { Tabel Acivity file } \\ \text { Primary key } & : & \text { Activity_id } \\ \text { Jumlah Field } & : & 2 \\ & & \text { TABLE III }\end{array}$

STRUKTUR FILE TABEL ACTIVITY FILE

\begin{tabular}{|l|l|l|c|}
\hline NO & Nama Feld & Type Data & Panjang \\
\hline 1 & Activity_Id $*$ & Integer & 11 \\
\hline 2 & File_id & Integer & 11 \\
\hline
\end{tabular}

Berikut struktur tabel pada tabel Board dapat dilihat pada Tabel 4:

Nama tabel : Tabel Board

Primary key

Jumlah Field

$$
\begin{gathered}
\text { Id } \\
6 \\
\text { TABLE IV }
\end{gathered}
$$

STRUKTUR FILE TABEL BOARD

\begin{tabular}{|l|l|l|l|}
\hline NO & Nama Feld & Type Data & Panjang \\
\hline 1 & Id $*$ & Integer & 11 \\
\hline 2 & Name & Varchar & 100 \\
\hline 3 & Description & Text & \\
\hline 4 & Created_at & Datetime & \\
\hline 5 & Update_at & Datetime & \\
\hline 6 & Deleted_at & Datetime & \\
\hline
\end{tabular}

Berikut struktur tabel pada tabel Board Cumulative Flow dapat dilihat pada Tabel 5:

$\begin{array}{lcc}\begin{array}{l}\text { Nama } \\ \text { tabel }\end{array} & : & \begin{array}{c}\text { TabelBoard } \\ \text { Cumulative Flow } \\ \text { Primary }\end{array} \\ \begin{array}{l}\text { key } \\ \text { Jumlah }\end{array} & : & \text { plan_id } \\ \text { Field } & : & 6\end{array}$

TABLE $V$

STRUKTUR FILE TABEL BOARD CUMULATIVE FLOW

\begin{tabular}{|l|l|l|l|}
\hline NO & Nama Feld & Type Data & Panjang \\
\hline 1 & plan_id $*$ & Integer & 11 \\
\hline 2 & board_id & Integer & 11 \\
\hline 3 & total & Integer & 11 \\
\hline 4 & d_day & Char & 8 \\
\hline 5 & d_month & Char & 6 \\
\hline 6 & d_year & Char & 4 \\
\hline
\end{tabular}

Berikut struktur tabel pada tabel Board Task Status dapat dilihat pada Tabel 6:

$$
\begin{array}{llll}
\text { Nama tabel } & : & \text { Tabel Board Task } \\
& \text { Status } & \\
\text { Primary key } & : & \text { board_id } \\
\text { Jumlah Field } & : & 2 & \\
& & \text { TABLE VI } &
\end{array}
$$

STRUKTUR FILE TABEL BOARD TASK STATUS

\begin{tabular}{|l|l|l|l} 
NO & Nama Feld & Type Data & Panjang \\
\hline
\end{tabular}




\begin{tabular}{|l|l|l|l|}
\hline 1 & board_id $*$ & Integer & 11 \\
\hline 2 & task_status_id & Integer & 11 \\
\hline
\end{tabular}

Berikut struktur tabel pada tabel file dapat dilihat pada Tabel 7 berikut ini :

Nama tabel

Primary key

Jumlah Field

Tabel File

plan_id

11

TABLE VII

STRUKTUR FILE TABEL FILE

\begin{tabular}{|l|l|l|c|}
\hline NO & Nama Feld & Type Data & Panjang \\
\hline 1 & id $*$ & Integer & 11 \\
\hline 2 & name & Varchar & 100 \\
\hline 3 & description & Text & \\
\hline 4 & path & Text & \\
\hline 5 & fullpath & Text & \\
\hline 6 & extension & Varchar & 20 \\
\hline 7 & size & Integer & 11 \\
\hline 8 & created_at & Datetime & \\
\hline 9 & updated_at & Datetime & \\
\hline 10 & deleted_at & Datetime & \\
\hline 11 & nik & Int & 11 \\
\hline
\end{tabular}

Berikut struktur tabel pada tabel member dapat dilihat pada Tabel 8 berikut ini :

Nama tabel

: Tabel member

Primary key

Nik

Jumlah Field

8

TABLE VIII

STRUKTUR FILE TABEL MEMBER

\begin{tabular}{|l|l|l|l|}
\hline NO & Nama Feld & Type Data & Panjang \\
\hline 1 & nik $*$ & Integer & 11 \\
\hline 2 & Name & Varchar & 100 \\
\hline 3 & Email & Varchar & 100 \\
\hline 4 & Team_id & Integer & 11 \\
\hline 5 & Job_role_id & Integer & 11 \\
\hline 6 & created_at & Datetime & \\
\hline 7 & updated_at & Datetime & \\
\hline 8 & deleted_at & Datetime & \\
\hline
\end{tabular}

Berikut struktur tabel pada tabel Group dapat dilihat pada Tabel 9:

Nama tabel

Primary key

Jumlah Field

$$
\begin{array}{cc}
: & \text { Tabel Group } \\
: & \text { Team_id } \\
: & 4 \\
& \text { TABLE IX }
\end{array}
$$

STRUKTUR FILE TABEL GROUP

\begin{tabular}{|l|l|l|l|}
\hline NO & Nama Feld & Type Data & Panjang \\
\hline 1 & Team_id $*$ & Integer & 11 \\
\hline 2 & Name & Varchar & 100 \\
\hline 3 & Description & Varchar & 100 \\
\hline 4 & date & Datetime & \\
\hline
\end{tabular}

Berikut struktur tabel pada tabel Group dapat dilihat pada Tabel 10 :

$\begin{array}{lll}\text { Nama tabel } & : & \text { Tabel Job Role } \\ \text { Primary key } & : & \text { Job_role_id } \\ \text { Jumlah Field } & : & 4 \\ & \text { TABLE } X\end{array}$

STRUKTUR FILE TABEL JOB ROLE

\begin{tabular}{|l|l|l|l|}
\hline NO & Nama Feld & Type Data & Panjang \\
\hline 1 & Job_rol_id $*$ & Integer & 11 \\
\hline
\end{tabular}

\begin{tabular}{|l|l|l|l|}
\hline 2 & Name & Varchar & 100 \\
\hline 3 & Description & Varchar & 100 \\
\hline 4 & date & Datetime & \\
\hline 5 & Parent & Integer & 11 \\
\hline
\end{tabular}

4. Implementasi Aplikasi

Untuk masuk kedalam aplikasi Task Management pengguna harus melakukan login terlebih dahulu dengan meng-input-kan username dan password masing-masing.

Login ke IP ebtask.com dengan user dan password yg sudah disediakan oleh administrator. Maka akan muncul halaman login yang dapat dilihat pada Gambar 18 :

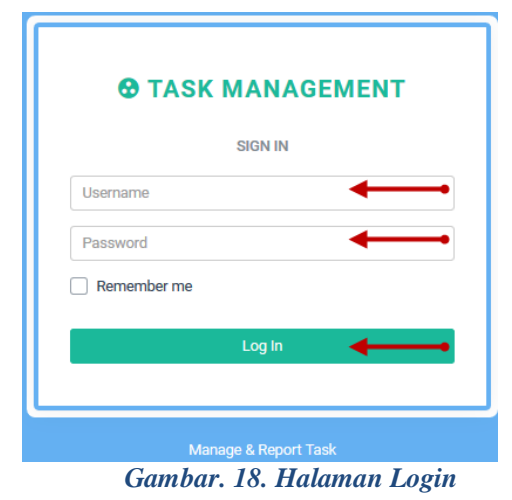

1) Halaman Home

Di halaman home ini pengguna dapat melihat list plan yang sedang dikerjakan (sebelah kiri) dan list task yang terakhir dikerjakan (sebalah kanan).

Jika login sudah benar, tampilan akan diarahkan ke halaman Dashboard pada Gambar 19:

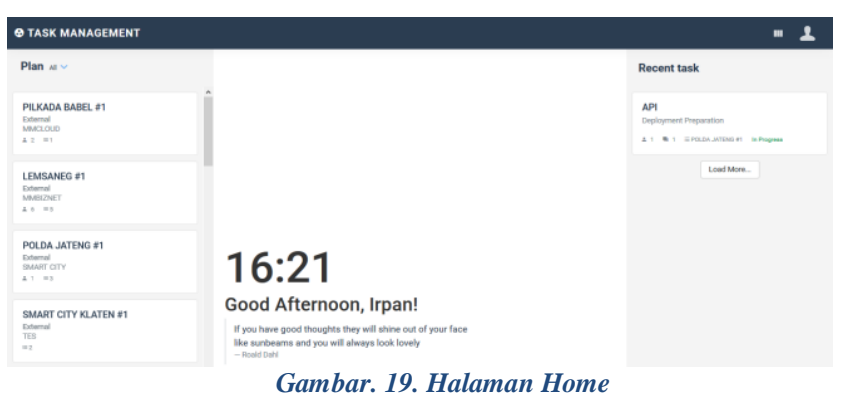

2) Halaman Board

Untuk melihat halaman board pengguna harus memilih salah satu plan yang tersedia. Seperti yang sudah dijelaskan di halaman home, list plan tersebut berada disebelah kiri.

Pilih nama (Plan) untuk menampilkan detil Board dan catatan penugasan dalam job terkait. Berikut tampilan halaman Board dapat dilihat pada Gambar 20:

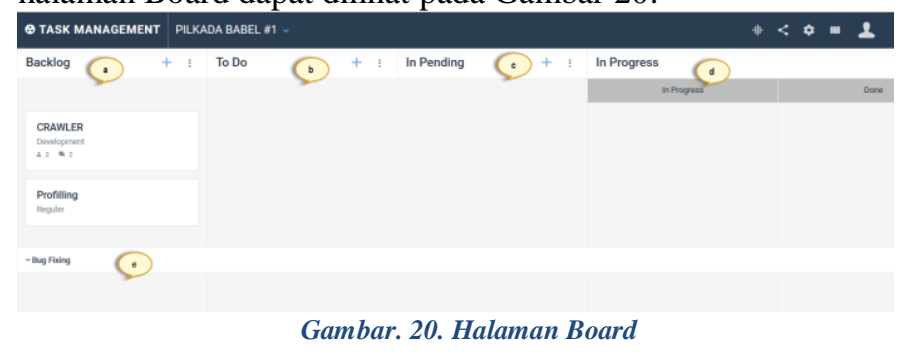

- Pilih Backlog untuk membuat task 
- Lalu To Do untuk meng-approve task yang sudah diberikan

- Kemudian In Pending bila task yang sudah diambil belum dikerjakan dikarenakan ada suatu hal.

- Setelah itu Kolom In Progress yang artinya task tersebut sedang dikerjan oleh pegawai, apabila sudah selesai maka task tersebut berpindah tempat ke kolom done.

- Kemudian ada kolom In Review apabila task yang sudah dikerjan dan sudah lolos unit test staging, maka task segera dicek oleh QA

- Apabila ada bug maka QA akan mengeceknya sampai tidak lagi terdapat bug dan siap di bangun.

Untuk melihat detail task maka klik salah satu task, maka akan muncul pop-up detail task seperti pada Gambar 21:

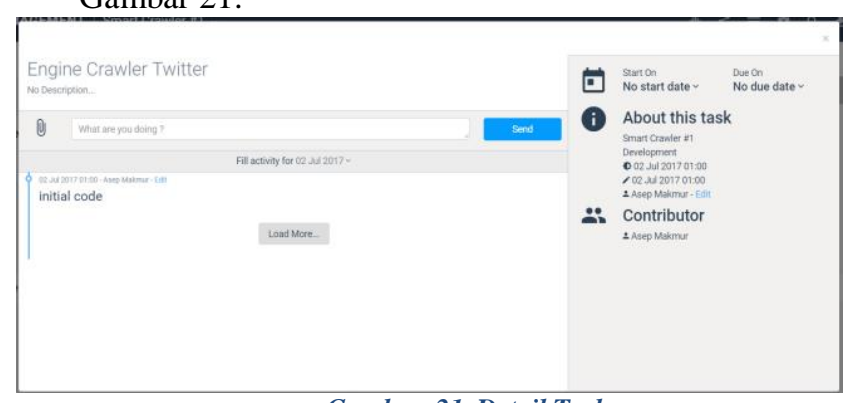

Gambar. 21. Detail Task

3) Halaman Analytics

Setelah berada di halaman board, untuk masuk ke halaman analytics pengguna tinggal memilih tombol “Analytic" ("Nי) maka pengguna akan langsung dialihkan ke halaman Analytics sesuai dengan plan yang sedang aktif. Di halaman analytics ini pengguna akan disuguhkan dengan visualisasi board dalam bentuk grafik sebagai acuan untuk melakukan proses analisa terhadap plan yang sedang aktif.

Berikut merupakan tampilan halaman analytics dapat dilihat pada Gambar. 22 :

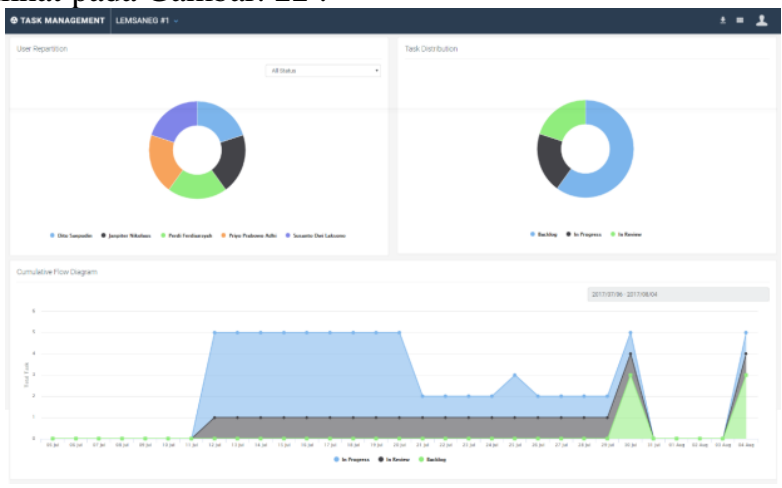

Gambar. 22. Halaman Analytics

4) Halaman Monitoring

Untuk masuk ke halaman monitoring maka pilih menu "Monitoring", maka akan tampil list plan terbaru, plan yang progress pengerjaannya terhambat dan plan yang mendekati tanggal deadline. Berikut tampilan halaman monitoring dapat dilihat pada Gambar. 23 :

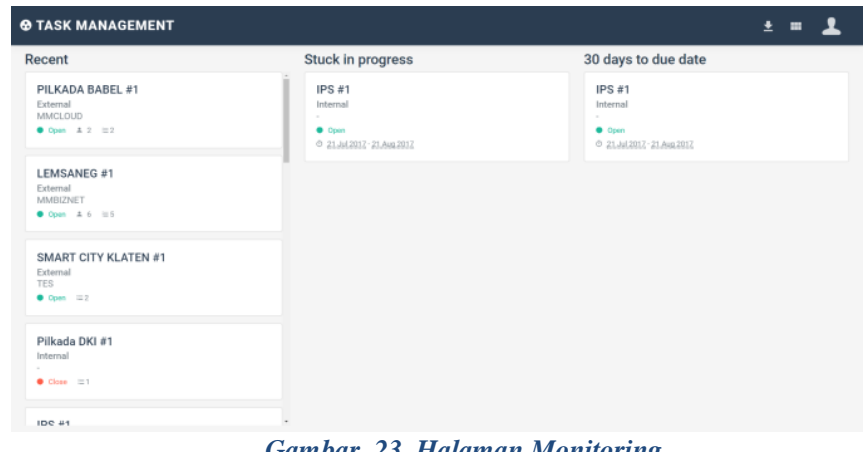

Gambar. 23. Halaman Monitoring

5) Halaman Review

Untuk masuk ke halaman review maka pilih menu "Review", maka akan tampil daftar aktifitas dalam bentuk kalender. Aktifitas tersebut dalam di filter berdasarkan Team, Plan dan Job Role.Berikut tampilan halaman review dapat dilihat pada Gambar. 24 :

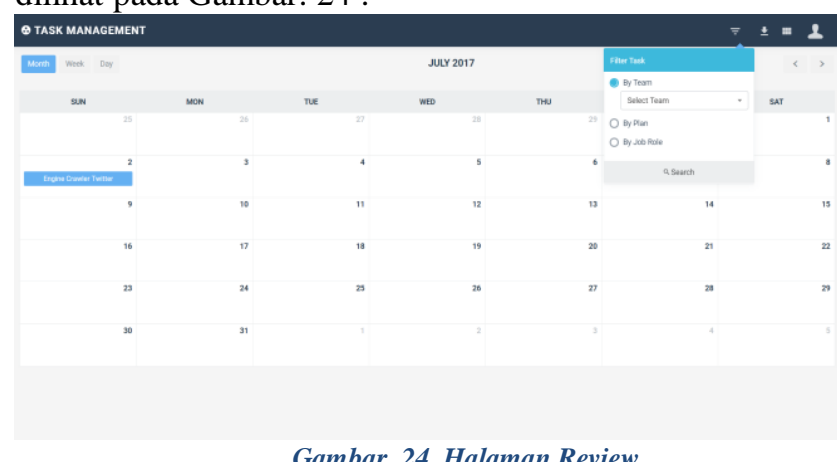

Gambar. 24. Halaman Review

6) Halaman Plan \& Task

Untuk masuk ke halaman plan \& task maka pilih menu "Plan \& Task". Di halaman ini pengguna dapat mengelola data master plan \& task. Pada saat membuka halaman Plan \& Task pengguna akan melihat list plan dan form create plan yang berfungsi untuk mengelola data master plan. Berikut tampilan halaman Plan \& Task dapat dilihat pada Gambar 25 :

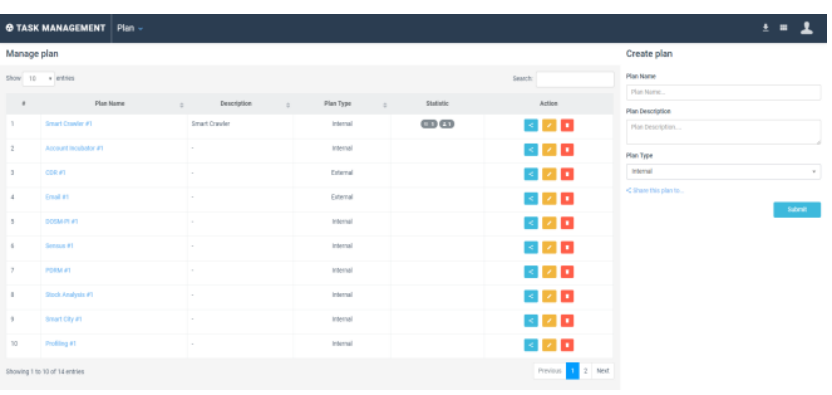

Gambar. 25. Halaman Plan \& Task

Untuk mengelola data master task maka pengguna tinggal memilih submenu "Task", maka akan tampil list task dan form create task.

Berikut merupakan tampilan halaman Plan \& Task submenu Task dapat dilihat pada Gambar. 26 : 


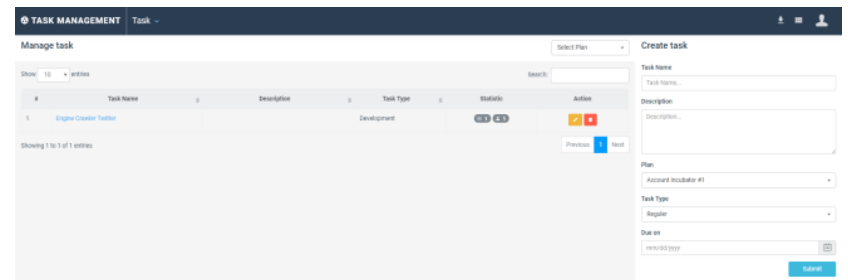

Gambar. 26. Halaman Plan \& Task submenu Task

7) Halaman Team

Untuk masuk ke halaman team maka pilih menu "Team", kemudian akan tampil list team di sebelah kiri dan form tambah team disebelah kanan. Di halaman ini pengguna dapat mengelola data master team. Berikut merupakan tampilan halaman team dapat dilihat pada Gambar. 27:

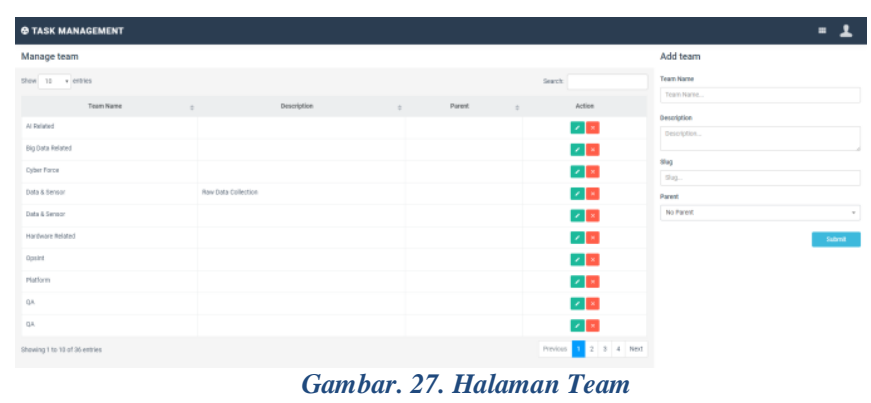

8) Halaman Member

Untuk masuk ke halaman member maka pilih menu "Member", kemudian akan tampil list member di sebelah kiri dan form tambah member disebelah kanan. Di halaman ini pengguna dapat mengelola data master member. Berikut merupakan tampilan halaman member dapat dilihat pada Gambar. 28 :.

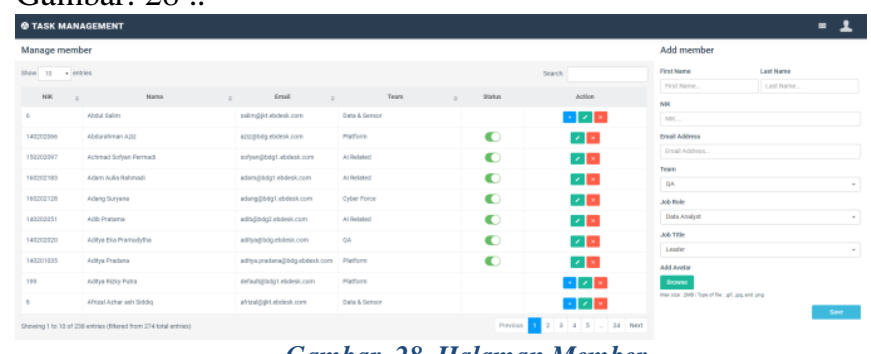

Gambar. 28. Halaman Member

9) Halaman Group

Untuk masuk ke halaman group maka pilih menu "Group", kemudian akan tampil list group. Di halaman ini pengguna dapat mengelola data master group. Berikut merupakan tampilan halaman group dapat dilihat pada Gambar. 29 :

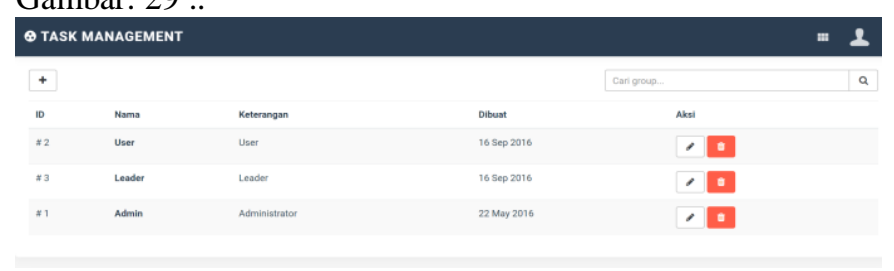

Gambar. 29. Halaman Group

10) Halaman User
Untuk masuk ke halaman user maka pilih menu "User", kemudian akan tampil list user. Di halaman ini pengguna dapat mengelola data master user.

Berikut merupakan tampilan halaman user dapat dilihat pada Gambar. 30 :.

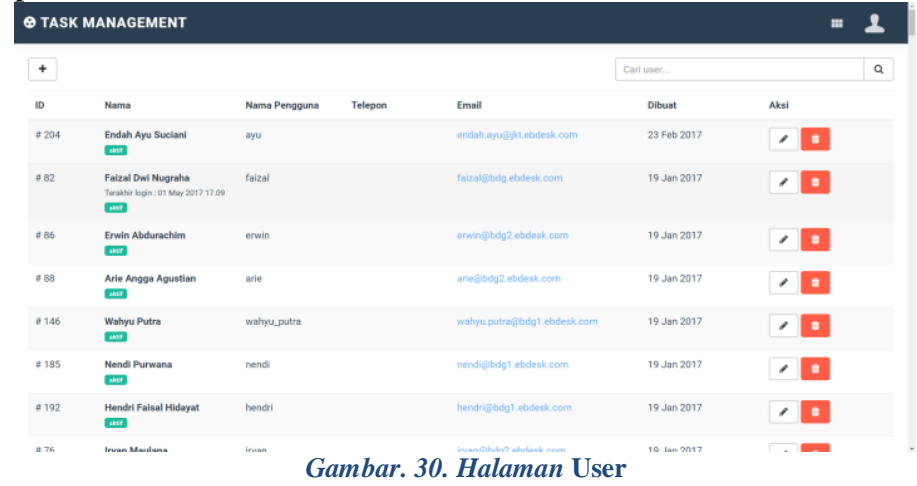

Dari hasil implementasi di atas, terdapat beberapa hasil diantaranya :

1. Distribusi pekerjaan : dengan menggunakan aplkasi task management, leader memberikan task kepada timnya melalui sistem informasi Task Management, sehingga tim akan mendapatkan pemberitahuan dari sistem mengenai task yang mereka dapatkan.

2. Pelaporan pekerjaan : dengan menggunakan aplikasi task management, anggota tim melaporkan hasil pekerjaannya melalui sistem informasi Task Management. Sehingga memudahkan leader dalam mengontrol pekerjaan tim.

3. monitoring progress plan : dengan menggunakan aplkasi task management, leader dan pihak manajemen lainnya untuk memantau progress plan, sehingga dapat memonitor dan evaluasi hasil kerja masing-masing projek.

4. Analisa dan Evaluasi : dengan menggunakan aplkasi task management, visualisasi dalam bentuk grafik maka sistem dapat memberikan informasi yang berguna untuk kebutuhan analisa dan evaluasi. Analisis di sini mencakup analisa progress suatu plan dan juga analisis sumber daya manusia, sehingga dari hasil analisis tersebut pihak menajemen dapat memberikan evaluasi kepada timnya.

\section{KESIMPULAN}

Berdasarkan penelitian dan hasil pengujian yang telah dilakukan terhadap Sistem Informasi Task Management di PT. eBdesk Teknologi, dapat ditarik beberapa kesimpulan sebagai berikut :

1. Setiap tahun PT.Ebdesk biasa menangani 5-7 proyek, proyek yang ditangani bervariasi meliputi eBdesk eXpander Corporate portal, eXpedition Workflow, eNcyclo Document Management, eXpert Knowledge Management dan lain-lain.

2. Terdapat 3 hak akses user yang akan digunakan dalam aplikasi Task Management, di antaranya : hak akases untuk Leader, member(karyawan) dan admin.

3. Dengan adanya fasilitas didalam aplikasi Sistem Informasi Task Management seperti monitoring progress plan, pelaporan pekerjaan serta distribusi 
pekerjaan sehingga dapat membantu leader dan anggotanya dalam mengelola proyek yang sedang berlangsung.

4. Pada aplikasi Task Management, rancangan arsitektur jaringan yang digunakan adalah berbasis website. Dimana terdapat 1 server yang digunakan untuk menyimpan aplikasi dan database aplikasi Task Management.

\section{UCAPAN TERIMA KASIH}

Dengan kerendahan hati, pada kesempatan ini penulis ingin menyampaikan rasa terima kasih kepada semua pihak yang telah memberi dorongan, motivasi dan bantuan baik moril maupun materil kepada penulis selama penulisan penelitian ini.

Pada kesempatan ini pula, penulis menyampaikan ucapan terima kasih yang sebesar-besarnya kepada :

A. PT.eBdesk Indonesia tempat penelitian dengan informasi serta data-data yang didapat.

B. Universitas Komputer Indonesia, home base penulis yang telah memberikan fasilitas kepada penulis saat melakukan penelitian.

\section{DAFTAR PUSTAKA}

[[1] A. Anggraini, "Pengaruh Pengawasan Supervisor dan Kinerja Karyawan AMIGO GROUP Cabang Granada Delanggu," 2010.

[[2] A. Hidayati, "Aplikasi Promanage (Proyek Manajemen) Berbasis Web di CV. Ixosoft Online Solution," 2015.

[[3] A. Rickayzen, Challenges for Business Process and Task Management, Walldorf Germany, 2004.

[[4] J. H. Mustakini, Sistem Informasi Teknologi, Yogyakarta: Andi Offset, 2009.

[[5] A. Mulyanto, Sistem Informasi Konsep \& Aplikasi,1st ed, Yogyakarta: Pustaka Pelajar, 2012.

[[6] K. Grundy, Educational Research In Australia, Australia, 1990. 